Al-Bayyinah: Journal of Islamic Law- ISSN: 1979-7486 (p); $\underline{2580-5088}$ (e) Volume VII Number 2, pp. 45 - 58

\title{
WASIAT YANG MENGHILANGKAN HAK WARIS KARENA ALASAN SILARIANG (KAWIN LARI) MENURUT PERSPEKTIF HUKUM ISLAM
}

\section{Hasyim Sofyan Lahilote}

(Dosen Fakultas Syariah dan Hukum IAIN Manado)

\section{Abstract}

This study shows that unrecognized heirs who make mistakes have the right to inherit as long as the heirs fulfill their inheritance rights and do not violate Islamic law and the existing problems should be forgiven and resolved so as not to harm the heirs who will receive inheritance. In connection with a will, an heir may not inherit inheritance to his heirs because the law is forbidden or contrary to syarit such as: inherited by saying: "inheritance for children is divided equally between men and women". Or "choose to love children in the distribution of inheritance, where there are those who get and there are also those who have their inheritance removed" Even the judges will not pass the will later when the division takes place because it is against the Shari'a.

\section{Kata Kunci: Wasiat, hak waris, silariang, hukum Islam}

\section{A. Latar Belakang}

Wasiat adalah satu dari bentuk-bentuk penyerahan atau pelepasan harta dan memiliki dasar hukum yang sangat kuat dalam syari'at Islam. Dalam praktek pelaksanaanya, pelaksanaan wasiat yang bertentangan dengan hukum kewarisan harus memenuhi beberapa persyaratan tertentu agar pelaksanaanya tidak bertentangan dengan ketentuan 
hukum waris dan tidak merugikan para ahli waris lain yang tidak memperoleh pemberian melalui wasiat. ${ }^{1}$

\section{B. Rumusan Masalah}

Adapun submasalah pda penelitian ini sebagai berikut:

1. Apa hukum tidak diakuinya seorang ahli waris karena alasan Silariang (kawin lari)?

2. Apa hukum wasiat dalam menghilangkan ahli waris yang tidak diakui karena alasan Silariang (kawin lari)?

\section{Tujuan dan Kegunaan Penelitian}

Adapun yang menjadi tujuan dalam penelitian ini adalah untuk mengetahui hukum tidak diakuinya seorang ahli waris karena alasan Silariang (kawin lari) dan untuk mengetahui hukum wasiat dalam menghilangkan ahli waris yang tidak diakui Silariang (kawin lari). Sedangkan, kegunaan penelitian sebagai berikut:

1. Secara teoritis, hasil penelitian ini diharapkan dapat memberikan sumbangan positif kepada seluruh komponen tentang hukum wasiat dan kewarisan baik bagi peneliti maupun pembaca, yang nantinya mampu memahami mengenai hukum wasiat dalam menghilangkan hak waris.

2. Secara praktis, penelitian ini menjadi sebagai salah satu bahan referensi bagi penelitian lainnya yang sejenis untuk menindak lanjuti hasil penelitian ini agar lebih luas lagi, dan juga sebagai bahan untuk memahami dan mencari penjabaran bagi masyarakat yang masih kurang paham mengenai hukum wasiat dalam menghilangkan hak waris.

\section{Metodologi Penelitian}

Penelitian ini merupakan penyajian data yang dilakukan secara deskriptif kualitatif dengan menggunakan pendekatan yuridis normatif dan pendekatan yuridis empirik.

Teknik pengumpulan data dilakukan melalui data primer (berupa data dan informasi langsung dari lokasi

${ }^{1}$ Ibrahim Ghazali, Pembagian Harta Pusaka dan Kepentingan Wasiat (Yogyakarta: 27 Maret, 2007), h. 63. 
penelitian) data sekunder (berupa data yang bersifat teori, yang diperoleh melalui hasil pengolahan pihak kedua dari hasil penelitian lapangan). Adapun instrumen yang digunakan, yaitu format observasi, format wawancara, dan alat dokumentasi.

Data yang dikumpulkan akan diolah dengan menggunakan teknik deduktif, kemudian dianalisis lebih lanjut dengan menggunakan metode kualitatif dengan 3 tahap, yaitu tahap reduksi data, display data, dan simpulan atau verifikasi.

\section{E. Hasil Pembahasan}

\section{Wasiat}

Kata wasiat berasal dari wașaya yang artinya orang yang berwasiat menghubungkan harta bendanya waktu hidup dengan sesudah mati. Dalam Kompilasi Hukum Islam pasal 171 huruf $\mathrm{F}$, wasiat adalah pemberian suatu benda dari pewaris kepada orang lain atau lembaga yang akan berlaku setelah pewaris meninggal dunia. ${ }^{2}$ Dalam buku Hukum Kewarisan Islam sebagai Pembaruan Hukum Positif di Indonesia, wasiat adalah pesan terakhir dari seseorang yang mendekati kematianya, dapat berupa pesan tentang apa yang harus dilaksanakan para penerima wasiat terhadap hasrat peninggalannya atau pesan lain di luar harta peninggalan. ${ }^{3}$

Denagn demikian, wasiat ialah peryataan atau perkataan seseorang kepada orang lain bahwa ia memberikan kepada orang lain itu hartanya tertentu atau membebaskan hutan orang itu atau memberikan manfaat sesuatu barang kepunyaan nya setelah ia meninggal dunia.

Wasiat itu ada dua macam, yaitu wasiat wajib (wajib atas orang yang memiliki hutang, menanggun hakhak, memiliki amanat dan janji) dan wasiat yang disunnahkan dan dianjurkan (berwasiat dengat sepertiga

${ }^{2}$ Undang-Undang Republik Indonesia Nomor 1 Tahun 1974 Tentang Perkawinan dan Kompilasi Hukum Islam (Cet. VI; Bandung: Citra Umbara, 2011), h. 291.

${ }^{3}$ Muh Muhibbin. Abdul Wahid, Hukum Kewarisan Islam Sebagai Pembaruan Hukum Positif di Indonesia (Jakarta: Sinar Grafika, 2009), h. 145. 
harta atau kurang dari itu, untuk selain ahli waris yang disalurkan untuk amal-amal kebajikan dan jalan kebaikan baik itu bersifat khusus, seperti fulan-baik, kerabat mau pun bukan kerabat, intansi tertentu.

Wasiat disyariatkan dan diperintahkan, sebagaimana dalam QS.al-Maidah/5:106. Ayat ini menjelaskan bahwa wasiat merupakan syari'at Islam yang mempunyai fungsi bagi manusia, sehingga tak ada seorang ulama atau orang Islam yang menentang dengan adanya wasiat, bahkan perbuatan ini banyak dilakukan oleh umat Islam masa lalu. Terdapat pula dalam hadist riwayat alBukhāri: 2533.

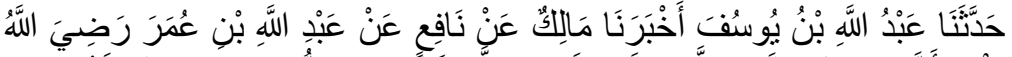

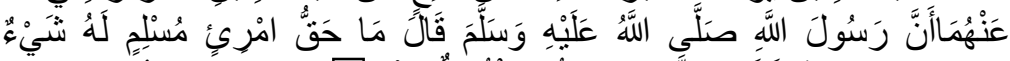

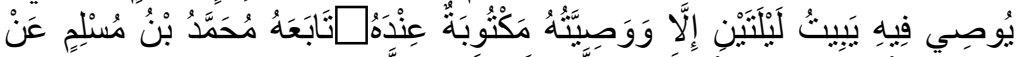

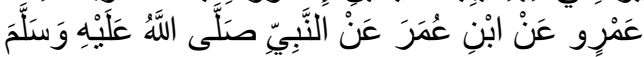

Artinya:

Telah bercerita kepada kami 'Abdullah bin Yusuf telah mengabarkan kepada kami Mālik dari Nafi' dari 'Abdullạ̄ bin 'Umar radiallāḥu 'anhumā bahwa Rasulullāh șallāllaḥu 'alaịịi wasallam bersabda: "Tidak ada haq seorang muslim yang mempunyai suatu barang yang akan diwasiatkannya, ia bermalam selama dua malam kecuali wasiatnya itu ditulis di sisinya". Hadits ini diikuti pula oleh Muhammad bin Muslim dari 'Amru dari Ibnū 'Umar dari Nabi șallāllahu 'alaihi wasallam. ${ }^{4}$

Ibnu Rusyd menyatakan, rukun wasiat ada 4, yaitu pemberi wasiat, penerima wasiat, barang yang diwasiatkan, dan siqhat. ${ }^{5}$ Dalam Kompilasi Hukum Islam seseorang yang akan berwasiat dijelaskan pada pasal 194 yang berbunyi:

\footnotetext{
${ }^{4}$ Lidwa Pusaka i-Software - Kitab 9 Imam Hadist, Kitab Bukhari
} No. 2533.

${ }^{5}$ Ibnu Rusyd, Bidayah Al Mujtahid wa Nihayah Al Muqtasid, Juz II (Bairut: Dar Al-Jiil, 1989), h. 374. 
a. Orang yang telah berumur sekurang-kurangnya 21 tahun. Berakal sehat dan tanpa adanya paksaan dapat mewasiatkan sebagian harta bendanya kepada orang lain atau lembaga.

b. Harta benda yang diwasiatkan harus merupakan hak dari pewasiat.

c. Pemilikan terhadap harta benda seperti dimaksud dalam ayat 1 pasal ini baru dapat dilaksanakan sesudah pewasiat meninggal dunia. ${ }^{6}$

Berdasarkan ketentuan dalam Kitab Undang-Undang Hukum Perdata kriteria pemberi wasiat diantaranya, pewaris pembuat surat wasiat harus berakal sehat (Pasal 856 KUHPdt), artinya tidak sakit berat yang mengakibatkan tidak dapat berpikir secara wajar. Jika surat wasiat memuat syarat-syarat yang tidak dapat dimengerti atau tidak mungkin dapat dilaksanakan atau bertentangan dengan kesusilaan, hal yang demikian itu harus dianggap tidak tertulis. Surat wasiat tidak boleh memuat ketentuan yang mengurangi bagian mutlak para ahli waris (Pasal 913 KUHPdt).

Apabila wasiat diberikan kepada ahli waris adapun syarat-syarat ahli waris sebagai berikut:

a. Hubungan pemasaban dari pernikahan yang sah secara Islam.

b. Hubungan pernikahan yang sah secara Islam dan masih berlangsung, termasuk nikah sirri.

c. Kesamaan agama Islam dan bukan aliran yang sesat dari ajaran Islam.

Harta atau barang yang diwasiatkan diisyaratkan sebagai harta yang dapat diserahterimakan hak pemilikannya dari pemberi wasiat kepada penerima wasiat. Sedangkan, ijab qabul adalah serah terima antara pemberi wasiat dengan penerima wasiat yang status pemilikannya berlaku sesudah pewasiat wafat dan diisyaratkan melalui lafal yang jelas mengenai barang atau harta yang menjadi objek wasiat, baik dan KHI, h. 298.

${ }^{6}$ Undang-Undang RI Nomor 1 Tahun 1974 Tentang Perkawinan

${ }^{7}$ Ahmad Bisyri Syakur, Panduan Lengkap Mudah Memahami Hukum Waris Islam Dilengkapi Hibah dan Wasiat (Jakarta: Visimedia Pustaka, 2015), h. 35. 
secara tertulis maupun secara lisan, yang kemudian disaksikan oleh dua orang saksi. ${ }^{8}$

Mekanisme pemberian wasiat, memiliki beberapa kesamaan terhadap ketentuan syarat-syarat kewarisan dalam Islam, diantaranya: Ada tiga syarat kewarisan, yaitu:

a. Meninggal dunianya pewaris,

b. Hidupnya ahli waris,

c. Mengetahui status kewarisan. ${ }^{9}$

Selain rukun dan syarat wasiat ada pula hal-hal yang dapat membatalkan wasiat:

a. Menarik wasiat, baik dengan kata-kata yang tegas maupun dengan indikasi

b. Menggantung wasiat pada syarat yang tidak akan terealisir.

c. Tidak ada harta waris yang menjadi letak wasiat.

d. Lenyapnya kecakapan pada diri pelaksana wasiat.

e. Kemurtadan orang yang berwasiat, menuerutnpendapat sebagian ulama.

f. Pengembalian wasiat dari orang yang diberi wasiat.

g. Orang yang diberi wasiat secara tertentu itu meninggal sebelu kematian yang member wasiat.

h. Orang yang diberi wasiat itu membunuh oran yang member wasiat.

i. Hancurnya apa yang diwasiatkan secara tertentu itu atau tampak kepemilikannya.

j. Wasiat menjadi batal, jika itu untuk ahli waris dan para ahli waris tidak membolehkannya. ${ }^{10}$

\section{Kewarisan dalam Islam}

Secara bahasa, waris berasal dari bahasa Arab yakni "warits" yang memiliki arti yang ditinggal atau yang kekal. Sedangkan secara istilah, makna waris kemudian diartikan sebagai orang-orang yang berhak untuk menerima pusaka dari

${ }^{8}$ Zainuddin Ali, Pelaksanaan Hukum Waris di Indonesia (Jakarta: Sinar Grafika, 2010), h. 23.

${ }^{9}$ Wati Rahmi Ria, Islamologi Suatu Pengantar Ilmu Hukum Islam (Bandung: Universitas Lampung, 2007), h. 45-46.

${ }^{10}$ Shalih b.Ghanim as-Sadlan , Tuntunan wakaf dan wasiat, h.42. 
harta yang ditinggalkan oleh orang yang telah mati yang juga dikenal dengan istilah ahli waris. ${ }^{11}$

Hukum waris dalam ajaran Islam disebut dengan istialah "Faraid". Kata Faraid adalah bentuk jamak dari kata faraidah yang berasal dari kata fardu yang berarti ketetapan dan pemberian (sedekah). Fardu dalam Alquran mengandung pengertian yaitu, kewajiban. Dalam Kompilasi Hukum Islam dijelaskan bahwa yang dimaksud dengan hukum kewarisan adalah hukum yang mengatur pemindahan hak kepemilikan harta peninggalan (Itirkah) pewaris, mentukan dab beberapa bagianya masing-masing ( pasal 171 ayat a KHI ). ${ }^{12}$

kewarisan,yaitu:

Dalam syariat Islam ada tiga syarat-syarat

a. Orang yang mewariskan (muwarris) benar telah meninggal dunia dan dapat dibuktuikan secara hukum bahwa ia telah meninggal dunia.

b. Orang yang mewarisi (ahli waris atau waris) hidup pada saat orang yang mewariskan meninggal dunia dan bisa dibuktikan secara hukum.

c. Ada hubungan pewaris antara orang yang mewariskan dengan orang yang mewarisi.

Adapun penghalang pewarisan (Mawani al-Irs), yaitu: pembunuhan, berlainan agama, dan perbudakan.

\section{Tabir, Halangan Mewarisi (Hijab)}

Hijab menurut bahasa berarti tabir, dinding, penghalang. Menurut istilah Faraid hijab adalah mencegah atau menghalangi orang tertentu untuk tidak berhak menerima bagian dari warisan atau menjadi penerima bagiannya, kareana adanya pewaris lain. Orang yang menjadi pengalang atau menghalangi orang lain mendapat warisan disebut hajib sedang orang terhalang mendapat warisan disebut mahjub.

${ }^{11}$ Suhrawardi K. Lubis dan Komis S, Hukum Waris Islam; Lengkap dan Praktis (Jakarta: Sinar Grafika, 2004), h. 52.

${ }^{12}$ Amin Husein Nasution, Hukum Kewarisan (Cet. II; Jakarta: RajaGrafindo Persada, 2012), h. 49. 
Istilah hijab dan mawani'ul iris mempunyai pengertian dan bahasa yang hampir bersamaan yaitu; halangan mendapat warisan, namun pada hakekatnya ada perbedaan antara keduanya, yaitu:

a. Halangan mewaris pada mawani'al irs adalah dengan usaha/perbuatan ahli waris itu sendiri, terhalang mewarisi pada hijab bukan karena perbuatan ahli waris yang bersangkutan. Penghalang pada mawani'al irs disebabkan suatu sifat atau sumber pada diri yang terhalang, sedang dalam masa hijab disebabkan adanya ahli waris yang lebih dekat denggan hubungan kerabatnya dengan si pewaris.

b. Status yang terhalang mendapat warisan dalam mawani'al irs dianggap tidak ada sama sekali, akan tetapi dalam masalah hijab, orang yang terhalang mendapat warisan (mahjub) dianggap tetap ada dan ia bisa tidak mendapat warisan sama sekali atau ia tetap mendapat harta warisan namun berkurang disebabkan dengan adanya pewaris yang menghalanginya, sehingga keberadaannya tetap menghalangi ahli waris yang lainnya. ${ }^{13}$

Hijab ada dua jenis, yaitu hijab hirman adalah terhalangnya seorang mendapat harta warisan kareana ada penghalangnya yang seseorang tersebut tidak mendapat harta warisan sama sekali, seperti kakek terhalng harta warisan karena ada ayah dan hijab nuqsan, yaitu terhalangnya seorang mendapat harta bagian warisan maksimal (berkurang harta warisan yang diterimanya karena ada penghalnang yang menyebabkan berkurangnya bagian ahli waris tersebut, seperti suami mendapat bagian warisan setengah apabila tidak ada ahli waris yang lain, akan tetapi terhalang mendapat bagian setengah karena ada anak dari yang meninggal, sehingga suami, hanya menerima bagian seperempat. ${ }^{14}$

${ }^{13}$ Amin Husein Nasution, Hukum Kewarisan, h. 84.

${ }^{14}$ Amin Husein Nasution, Hukum Kewarisan, h. 86. 


\section{Hukum Tidak Diakuinya Ahli Waris Karena Alasan Silariang (Kawin Lari)}

Berdasarkan firman Allah dalam QS An-Nisa: 7 menyatakan bahwa tiap ahli waris berhak mendapatkan warisan dan bagiannya masing-masing sesuai ketetapan hukum Islam. Tetapi kasus yang timbul dikalangan masyarakat sangatlah beranekaragam salah satunya terjadinya Kawin Lari karena tidak mendapat restu orang tuanya. Sehingga mengakibatkan ahli waris dihilangkan hak warisnya karena melakukan kesalahan yang mengakibatkan dirinya dikeluarkan sebagai ahli waris. $^{15}$

Kawin lari adalah masalah yang sering kerap terjadi dalam masyarakat baik dikalangan remaja yang tidak mendapat restu oleh orang tuanya maupun di dalam suatu pernikahan yang terjadi akibat perselingkuhan. ${ }^{16}$ Berdasarkan yang dikemukakan warga di Manado mengenai kasus-kasus kawin lari yang terjadi:

Seperti yang dikatakan oleh Manasia bahwa:

Kasus silariang yang terjadi pada kemanakannya yang sudah bersuami dan memiliki 2 orang anak, terjadi akibat mengenal seorang lelaki lewat media sosial. Sehingga dia diajak kabur oleh lelaki tersebut dengan meninggalkan suami dan dua orang anaknya. Akibatnya membuat dirinya diceraikan oleh suaminya dan dihilangkan hak warisnya oleh orang tuanya, dan diahlikan kepada suaminya yang bertanggung jawab mengurus anakanaknya. Perbuatan silariangnya tersebut membuat orang tuanya jatuh sakit, sehingga dirinya sudah tidak diakui lagi sebagai anak oleh orang tuanya sendiri. ${ }^{17}$

Berdasarkan wawancara tersebut maka dapat dipahami bahwa salah satu faktor lain yang menyebabkan kawin lari adalah karena tidak adanya restu dari orang tua untuk menikahkan anaknya kepada orang yang dicintainya. Sehingga sang anak memutuskan untuk kawin lari dan bahkan melakukan perbuatan yang dilarang oleh Allah swt., yakni mencuri.

\footnotetext{
${ }^{15}$ Amin Husein Nasution, Hukum Kewarisan, h.51

${ }^{16}$ Sarlito W.Sarwono, Psikologi Remaja (Rajawali Pers: 2006 ), h.

97.

${ }^{17}$ Manasia, Warga Desa Lappani, Wawancara oleh Penulis pada tanggal 29 Agustus 2018.
} 
Perbuatan tersebut bukanlah perbuatan yang baik akan tetapi termasuk perbuatan yang tercela di sisi Allah.

Melihat masalah-masalah yang kerap terjadi di dalam lingkungan masyarakat, hal mana ahli waris yang melakukan kesalahan tetap berhak untuk mendapatkan bagian warisannya, selama para ahli waris masih memenuhi hak-hak kewarisan dan tidak melanggar syariat hukum Islam. Jadi hendaknya kesalahan yang dilakukan ahli waris masih bisa diselesaikan hendaknya diselesaikan dan mencari jalan keluar dari masalah tersebut, sehingga tidak merugikan para ahli waris.

Perlu diketahui, ketika orang tua tidak mengakui anaknya karena Silariang maka orang tua harus tetap memberikan harta warisan karena pada dasarnya sang anak memiliki hak akan hal tersebut. Hal ini dapat dilihat berdasarkan QS. al-Nisā/4': 11 dan sabda Rasulullah saw. sebagai berikut:

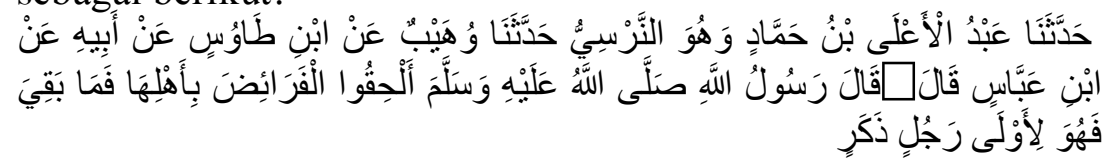

Artinya:

Telah menceritakan kepada kami Abdul A'la bin Hammād yaitu Al-Narsi- telah menceritakan kepada kami Wuhaīb dari Ibnu Tậ̄ūs dari Ayahnya dari Ibnu Abbās dia berkata, "Rasūlullāh sallallahu 'alaihi wasallam bersabda: "Berikanlah harta warisan kepada yang berhak mendapatkannya, sedangkan sisanya untuk laki-laki yang paling dekat garis keturunannya." 19

\section{Hukum Wasiat dalam Menghilangkan Ahli Waris yang Tidak Diakui Karena Alasan Silariang (Kawin Lari)}

Walaupun wasiat merupakan salah satu bentuk pemberian. Namun, wasiat memiliki perbedaan hukum. Hibah/pemberian berlaku saat yang memberi masih hidup, sementara pemberian yang mensyaratkan berlakunya setelah si pemberi meninggal dunia disebut sebagai wasiat.

\footnotetext{
Bintang), h. 25.

${ }^{19}$ Lidwa Pusaka i-Software - Kitab 9 Imam Hadist, Kitab Muslim No. 3028 .
}

${ }^{18}$ M. Ali Hasan, Hukum Waris dalam Islam (Jakarta: PT. Bulan 
Wasiat memiliki beberapa ketentuan meliputi bahwa orang yang berwasiat boleh meralat atau mengubah isi wasiat, tidak boleh wasiat harta melebihi sepertiga dari jumlah total kekayaan, dianjurkan agar kurang dari sepertiga, yang terbaik adalah mencukupkan diri dengan berwasiat seperlima dari jumlah total kekayaannya., larangan untuk berwasiat dengan lebih dari sepertiga itu hanya berlaku bagi orang yang memiliki ahli waris. Sedangkan orang yang sama sekali tidak memiliki ahli waris diperbolehkan berwasiat dengan seluruh hartanya, wasiat lebih dari sepertiga boleh dilaksanakan manakala seluruh ahli waris menyetujuinya dan tidak mempermasalahkannya, tidak diperbolehkan dan tidak sah wasiat harta yang diberikan kepada ahli waris yang mendapatkan warisan meski dengan nominal kecil, kecuali jika seluruh ahli waris sepakat membolehkannya, setelah pemberi wasiat meninggal dan jika wasiat harta untuk orang yang mendapatkan warisan ternyata hanya disetujui oleh sebagian ahli waris karena sebagian yang lain menyatakan ketidaksetujuannya. Isi wasiat dalam kondisi ini hanya bisa dilaksanakan pada bagian yang menyetujui isi wasiat, namun tidak bisa diberlakukan pada bagian warisan yang tidak menyetujuinya. ${ }^{20}$

Permasalahan penggunaan wasiat dalam pembagian harta warisan masih kurang dalam pemahaman masyarakat, khususnya masyrakat yang minim akan pengatahuan wasiat. Seperti kasus yang yang dikemukakan oleh warga warga kota Manado tentang wasiat yang menghilangkan hak waris karena alasan silariang (kawin lari).

Berdasarkan hasil wawancara yang didapatkan di lokasi penelitian, dapat dipahami bahwa sebagai orang tua mempunyai kewajiban memberi nafkah kepada keturunannya dan sekaligus akan dimintai tanggung jawab akan harta yang diberikan kepada ahli warisnya. Oleh karena itu, pertimbangkan terlebih dahulu kebutuhan sang anak tersebut masuk dalam kategori yang mana, sebelum memberikan harta bagian ahli

20 Aris Munandar MPI, Wasiat Yang Sesuai Syariat, http://pengusahamuslim.com/3741-wasiat-yang-sesuai-syariat-1907.html. 
warisnya. Hak waris seorang ahli waris durhaka tidak gugur, apabila semua syarat-syarat akan waris terpenuhi dan tidak bertentangan dengan hukum keislaman karena kedurhakaannya tidak menghalangi haknya tersebut.

Diantara wasiat yang diharamkan adalah: berwasiat untuk ahli waris yang menghilangkan hak kewarisannya, Nabi shallallaahu'alaihi wasallam bersabda:

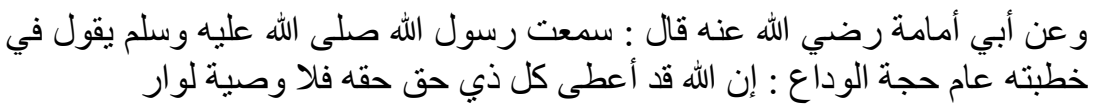
Artinya:

Dari Abì Umāmah raḍiallāhu 'anhu dia berkata: aku mendengar Rasūlullāhi șallallaahu'alihi wasallam bersabda pada kutbah di Haji Perpisahan: "Sesungguhnya Allah telah memberikan setiap ahli waris bagian dari haknya maka tidak boleh ada wasiat (yang diberikan) kepada ahli waris". HR Abū Dawūd dan Ibnū Mājah dan dishohihkan oleh syekh Al Albani. $^{21}$

Hadits ini bahkan menjadi nasikh (penghapus) hukum yang terdapat dalam surat Al-Baqarah ayat ke: 180 yang menganjurkan kepada seseorang untuk memberi wasiat kepada kedua orang tua (sebagai ahli waris) dan juga kerabat, karena dalam hadits di atas disebutkan kejadiannya terjadi tepat sebelum Nabi saw., meninggal yaitu pada saat haji perpisahan. Hal itu menunjukkan syariat yang turun terakhir dengan hukum yang menghapus hukum yang berlaku sebelumnya. ${ }^{22}$ Dengan demikian, maka sangat perlu memahami ketentuan-ketentuan hukum wasiat terutama mengenai wasiat dalam pembagian warisan.

Berdasarkan hal tersebut dapat dipahami bahwa hukum wasiat dalam menghilangkan ahli waris yang tidak diakui karena alasan silariang (kawin lari) tidak dibolehkan. Orang tua tidak boleh berwasiat dengan sesuatu yang diharamkan atau

${ }^{21}$ Lihat Misykatul Mashoobih hadits no: 3074 pada maktabah syamilah.

${ }^{22}$ Amin Husein Nasution, Hukum Kewarisan, h. 84. 
bertentangan dengan pembagian warisan untuk ahli warisnya, seperti: berwasiat dengan mengatakan "harta warisan untuk anak-anak dibagi sama rata antara laki-laki dan wanita". Ataupun "memilihkasihkan anak dalam pembagian harta warisan, hal mana ada yang mendapat harta warisan lebih dan ada pula yang dihilangkan hak warisnya". Bahkan hakim pun tidak akan meluluskan wasiat tersebut yang dilakukan nantinya pada saat pembagian warisan berlangsung karena bertentangan dengan syareat hukum Islam.

\section{F. Penutup}

Adapun simpulan dirumuskan dalam penelitin ini sebagai berikut:

1. Tidak diakuinya ahli waris karena silariang (kawin lari) merupakan hal yang keliru dan orang tua tidaklah seharusnya melakukan hal yang demikian. Perlu dipahami bahwa dalam pembagian warisan, ahli waris yang mendapat bagian lebih dahulu adalah ahli waris golongan ashhabul-furudh (ahli waris yang bagian mereka sudah tertentu), kemudian kalau ada sisanya baru diberikan kepada ahli waris golongan 'ashabah (ahli waris penerima sisa). Sehingga dengan demikian, bahwa ketika orang tua tidak mengakui anaknya karena Silariang maka orang tua harus tetap memberikan harta warisan karena pada dasarnya sang anak memiliki hak akan hal tersebut.

2. Hukum wasiat dalam menghilangkan ahli waris yang tidak diakui karena alasan silariang (kawin lari) tidak dibolehkan. Orang tua tidak boleh berwasiat dengan sesuatu yang diharamkan atau bertentangan dengan pembagian warisan untuk ahli warisnya, seperti: berwasiat dengan mengatakan "harta warisan untuk anakanak dibagi sama rata antara laki-laki dan wanita". Ataupun "memilihkasihkan anak dalam pembagian harta warisan, dimana ada yang mendapat harta warisan lebih dan ada pula yang dihilangkan hak warisnya". Bahkan hakim pun tidak akan meluluskan wasiat tersebut yang dilakukan nantinya pada saat pembagian warisan berlangsung karena bertentangan dengan syareat hukum Islam. 


\section{G. Daftar Pustaka}

Ali, Zainuddin. Pelaksanaan Hukum Waris di Indonesia. Jakarta: Sinar Grafika, 2010.

Ghazali, Ibrahim. Pembagian Harta Pusaka dan Kepentingan Wasiat. Yogyakarta: 27 Maret, 2007.

Hasan, M. Ali. Hukum Waris dalam Islam. Jakarta: PT. Bulan Bintang.

Lidwa Pusaka i-Software - Kitab 9 Imam Hadist, Kitab Bukhari No. 2533.

Lubis, Suhrawardi K. dan Komis S. Hukum Waris Islam; Lengkap dan Praktis. Jakarta: Sinar Grafika, 2004.

Munandar, Aris. Wasiat Yang Sesuai Syariat, http://pengusahamuslim.com/3741-wasiat-yang-sesuaisyariat-1907.html.

Nasution, Amin Husein. Hukum Kewarisan. Cet. II; Jakarta: RajaGrafindo Persada, 2012.

Ria, Wati Rahmi. Islamologi Suatu Pengantar Ilmu Hukum Islam. Bandung: Universitas Lampung, 2007.

Rusyd, Ibnu. Bidayah Al Mujtahid wa Nihayah Al Muqtasid, Juz II. Bairut: Dar Al-Jiil, 1989.

as-Sadlan, Shalih b.Ghanim. Tuntunan wakaf dan wasiat.

Sarwono, Sarlito W. Psikologi Remaja. Rajawali Pers: 2006.

Syakur, Ahmad Bisyri. Panduan Lengkap Mudah Memahami Hukum Waris Islam Dilengkapi Hibah dan Wasiat. Jakarta: Visimedia Pustaka, 2015.

Undang-Undang Republik Indonesia Nomor 1 Tahun 1974 Tentang Perkawinan dan Kompilasi Hukum Islam. Cet. VI; Bandung: Citra Umbara, 2011.

Wahid, Muh Muhibbin Abdul. Hukum Kewarisan Islam Sebagai Pembaruan Hukum Positif di Indonesia. Jakarta: Sinar Grafika, 2009. 